\title{
SAILing toward larger protein structures
}

With a new method for optimizing the amino acid isotopic labeling pattern, stereoarray isotope labeling (SAIL), structures of large proteins (up to $50 \mathrm{kDa}$ ) can now be solved with ease with nuclear magnetic resonance (NMR) spectroscopy.

NMR spectroscopy has been rapidly catching up to crystallography as a powerful tool for solving three-dimensional protein structures. But as proteins increase in size, their NMR spectra become increasingly complex, making structural solution nearly impossible. This fact is reflected in the very low occurrence of NMR structures of proteins greater than $25 \mathrm{kDa}$ in the Protein Data Bank.

Traditionally, researchers uniformly label proteins with ${ }^{13} \mathrm{C}$ and ${ }^{15} \mathrm{~N}$ to enhance the NMR signals of these naturally lowabundance isotopes. In addition, exchanging protons for NMR-silent deuterium helps to simplify spectra. Though this strategy works well for small proteins, it is well-recognized to be ineffective for large proteins. Now, led by Masatsune Kainosho, researchers from Tokyo Metropolitan University aim to revolutionize the work of structural biologists by developing an optimal isotopic labeling method, SAIL.
SAIL uses a cell-free translation system to assemble proteins from synthetic stereoisotope-labeled amino acids. In contrast to traditional uniform labeling, the basic idea is to strip down the NMR-observable ${ }^{1} \mathrm{H}$ and ${ }^{13} \mathrm{C}$ signals from each amino acid to the bare minimum. This is done by stereospecifically replacing each $-{ }^{13} \mathrm{C}\left({ }^{1} \mathrm{H}\right)_{2}$ - unit with $-{ }^{13} \mathrm{C}\left({ }^{1} \mathrm{H},{ }^{2} \mathrm{H}\right)$ - and each $-{ }^{13} \mathrm{C}\left({ }^{1} \mathrm{H}\right)_{3}$ unit with $-{ }^{13} \mathrm{C}\left({ }^{1} \mathrm{H},{ }^{2} \mathrm{H},{ }^{2} \mathrm{H}\right)$. In addition, redundant methyl groups are made silent by conversion to $-{ }^{12} \mathrm{C}\left({ }^{2} \mathrm{H}\right)_{3}$. Similar strategies are used to simplify signals from side-chain rings. The optimal isotopic labeling pattern dramatically improves spectral quality, resulting in fewer signals, sharper line widths, simplified coupling patterns and unambiguous stereo assignment, all of which speed up the processing of NMR data for proteins of any size. But SAIL really blows open the door for solving NMR structures of large proteins, as Kainosho and his colleagues demonstrated with the 41 $\mathrm{kDa}$ maltodextrin-binding protein.

Kainosho has great expectations for the application of SAIL in structural biology, as he says: "The SAIL method is a basic technology to improve all protein NMR spectra, and there is no reason...to keep using conventional labeling methods." He does acknowledge, however, that the time and expense involved with synthesizing the SAIL amino acids is impractical for most labs. Kainosho hopes that a demand for the SAIL amino acids will push grant agencies (both Japanese and foreign) to support further development of the method. A venture company is poised to begin producing and selling the SAIL amino acids later this year.

SAIL should help NMR spectroscopy to cruise into position as a technique complimentary to crystallography in structural proteomics efforts. "With the help of SAIL, there will soon be no 'low hanging fruits'. Therefore, NMR spectroscopy will be applied to more biologically and medically relevant proteins." says Kainosho. With improvements to SAIL, he hopes to be able to solve the structures of membrane-bound proteins and large protein complexes up to $100 \mathrm{kDa}$.

\section{Allison Doerr}

\section{RESEARCH PAPERS}

Kainosho, M. et al. Optimal isotope labeling for NMR protein structure determinations. Nature 440, 52-57 (2006). 